研 究

ヨノン類の光酸素化反応について*

㞋奈和夫**・衛藤英男 ${ }^{* * *}$

Photo-Oxygenation of Ionones

Kazuo Ina and Hideo EtoH

Photo-oxygenation of ionones was studied to clarify the relation between aging of flavor in foods and the effect of several compounds in foods.

Flavons, fatty acids and alcohols protect the conversion of ionones, but gelatine and corn starch promote the change.

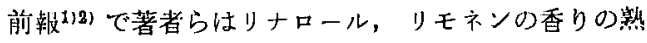
成家知る目的で，光酸素化反心を用い，その機構の検討 をしてきた。著者らはまたこれとは別にヨノン類の光 酸素化反応の機楆についても検討しだ!。

ヨノン類の光酸菜化反応により生成寸る物質のいくつ<smiles>CC(=O)/C=C/C12OC1CCCC2(C)C</smiles>

2,3-epoxy- $\beta$-ionone<smiles>CC(=O)/C=C\C1=CC(=O)CCC1(C)C</smiles>
cis-4-keto- $\beta$-ionone<smiles>CC1CCC(C)(C)C2=CC(=O)OC21C</smiles>

4-hydroxydihydroactinidiolide

Fig. 1. Oxygenated derivatives of $\beta$-ionone
かのものは最近種ヶの值物から微量の成分として分﨎さ れており (4)7)，これらの多くが香りと密接な関係を持っ ている。

ヨノン類は一般に熟成により香りはよくなるといわれ るが，この香りの熟成を光酸素化反応を用いて調べ，さ らにこれにいるいろな添加物定加えてヨノンの香りの熟 成に及ぼす影樂を調べた。

\section{1. 実験方法}

(1) 自動酸化反応

まずヨノンの香りの熟成の要因の一つに酸化が考えら れるので， $\beta$ れョノンの自動酸化を行なうために次の方法 で実験した。

防ノン $0.1 \mathrm{~g}$ をシリカゲル $5 \mathrm{~g}$ に吸着させ, 直径 $18 \mathrm{~cm}$ のシャーレに抗げ暗室内に静置し, 酸化の状態を 知るため一定時間ごとに試料を採取する。試料の採取は シリカゲルを充分量のエーテルに浸し，エーテル抽出し たのち，エーテルを留去し, 残液をガスクロマトグラフ

(GLC) に注入してその変化の状態を調べた。

(2) 三重項酸素酸化（光酸素化反応）

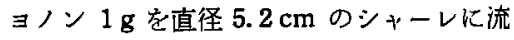
し込み，暗室内で前㪕めの方法に準じて光照 射した。試料の酸化の状態を知るため自動酸 化の場合と同じく, 試料を GLC に注入し検 討した。

(3) 各種添加物の影響

$\beta-\Xi ノ ン 0.1 \mathrm{~g}$ と添加物 $25 \mathrm{mg}$ を直径 1,1,3,-trimethyl3,4-epoxycyclohexyliden-2acetaldehyde $5.2 \mathrm{~cm}$ のシャーレに入れ，これにメタノー ル $1 \mathrm{~m} l$ と水 $5 \mathrm{~m} l$ を加えて均一としたのち, $10 \mathrm{~W}$ の蛊光灯 (白色) の下 $10 \mathrm{~cm}$ のところ に静置した。分析は反応 200 時間後の主生成 物 (2,3-Epoxy- $\beta$-ionone) (A) と残存 $\beta$-ヨ) ソ(B)の量が対照では $1: 1$ となるので，これ を基に添加物を加えたときの GLC上の (A) と (B)とのピーク面積比を求め対照と比較して添

\footnotetext{
*食品の香りの熟成について（第 3 報） Aging of Flavor in Foods, Part III.

** 静岡大学農学部 (静岡市大谷 836) Department of Agricultural Chemistry, Shizuoka University. Shizuoka, Shizuoka-ken.

****名城大学薬学部 (名古屋市昭和区天白町八事) Department of Pharmacy, Meijio University, Nagoya, Aichi-ken.
} 
<smiles>CC(=O)/C=C/C1C2OC2CCC1(C)C</smiles>

3,4-epoxy- $\alpha$-ionone<smiles>CC(=O)/C=C/C1C(O)C(O)CCC1(C)C</smiles>

3,4-dihydroxy-a-ionone<smiles>CC(=O)/C=C/C1C=CC(=O)CC1(C)C</smiles>

5-ket o- $\alpha$-ionone<smiles>CC(=O)/C=C/C1(O)C=CC(=O)CC1(C)C</smiles>

2-hydroxy-5-keto- $\alpha$-ionone<smiles>CC(=O)/C=C\C1=C(C)C(=O)CCC1(C)C</smiles>

cis-4-keto- $\beta$-ionone<smiles>CC(=O)/C=C\C1C(C)=CCCC1(C)C</smiles>

cis- $\alpha$-ionone<smiles>CC(=O)/C=C/C1=C(C)C(=O)CCC1(C)C</smiles>

4 -keto- $\beta$-ionone
2, 実験結果および考察

(1) 自動酸化反忠

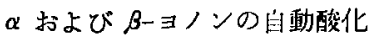

自動酸化では反念は全般に緩慢で, $\beta$-ヨ， ンでは約 2 力月後ごろから徐々にふ化が始ま り，最初に生成する物質は 2，3-Epoxy- $\beta-$ iononeであった。その後も変化は徐なに進 み, 約 20 力月後の反応液它分析した結果, Table 1 に示すような物質が同定された。こ

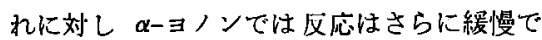
約 6 力月後において環の 2 重結合の酸化によ って生成した 3，4-Epoxy- $\alpha$-ionone の生成 が認められたのみであった。

(2) 三重項酸素酸化

i) $\beta$-ョノンについて

反応 2 日目ごろから 2,3-Epoxy- $\beta$-ionone の生成が始まり，その後急激に反応が進み， 他の各成分が同時に生成した。反応 4 日目の 液を分析すると Table 1 のようで， 7 種の 成分の存在が倠悲された。

Fig. 2. Oxygenated derivatives of $\alpha$-ionone

加物の酸化に対する影賖を検討した。

(4) GLC

前記反応により得られた生成物を確濯するため GLC による分析を行った。

GLC: Yanaco $550 \mathrm{FP}$, カラム：10\% DEGS, Celite $545,60 \sim 80$ mesh, $3 \mathrm{~mm}$ i.d., $75 \mathrm{~cm}$, 温度 $120 \sim$ $200^{\circ} \mathrm{C}$ ( $4^{\circ} \mathrm{C}$ 昇温), $\mathrm{N}_{2}: 25 \mathrm{ml} / \mathrm{min}$.

(5) 物質の同定

物質の同定にはおむに GC-MSを用い。前報8〉のチャ ートと比較して構造を検討した。実験に用いた機器は日 立製作所製 RMU-6GC，カラムは GLC 分析の場合と 同一物を用いた。

Table 1. Oxygenated derivatives of $\beta$-ionone by auto-oxy-genation and triplet $\mathrm{O}_{2}$ oxygenation

\begin{tabular}{|c|c|c|}
\hline Compounds & $\begin{array}{l}\text { Auto-oxy. } \\
\text { after } \\
20 \text { monthes }\end{array}$ & $\begin{array}{l}\text { Triplet } \mathrm{O}_{2} \text { oxy. } \\
\text { after } 96 \mathrm{hrs}\end{array}$ \\
\hline 2, 3-epoxy-a-ionone & + & + \\
\hline $\begin{array}{l}\text { 1, 1, 3-trimethyl-3, 4-epoxy- } \\
\text { cyclohexyliden-2-acetaldehyde }\end{array}$ & + & + \\
\hline dihydroactinidiolide & - & + \\
\hline cis-4-keto- $\beta$-ionone & - & + \\
\hline 4-keto- $\beta$-ionone & + & + \\
\hline 2. 3-dihydroxy- $\beta$-ionone & + & + \\
\hline 4-hydroxydihydroactinidiolide & - & + \\
\hline
\end{tabular}

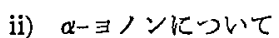

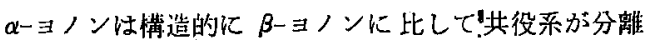
しており酸化に対し $\beta$ てでンよりも安定である。

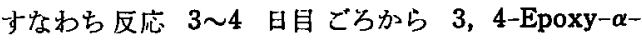
ionone の生成が始まり，その後徐々に反応が進み，反 心 14 日目で 8 種の成分が同定されこれれら Table 2 のようであった。

以上の結果からヨ/ン類では自動酸化, 三重項酸素酸 化，ともに比較的類似の成分が分離され，おとらく酸化 の機構が類似しているものと考えられた。中でも反后の 初期段階では両酸化ともエポキシ化がおむな反応であ り, ヨノン類の酸化の程度を知る一つの方法としてはェ ポキショノンと残存ヨノンの量を測定することで可能と 考えた。そこで $\beta$-ヨノンの残存量と 2,3-Epoxy- $\beta-$ ionone の生成量を $\alpha$-ヨノンを内部標準物質として GLC にて分析すると Fig. 3 のような関係が得られた。

(3) $\beta$-ヨノンの酸化におよぼす添加物の影響

Table 2. Oxygenated derivatives of $\alpha$-ionone by triplet $\mathrm{O}_{2}$ oxygenation (after 14 days)

Compounds; cis- $\alpha$-ionone, 3, 4-epoxy- $\alpha$-ionone, cis-4-keto$\beta$-ionone, 4-keto- $\beta$-ionone, 5-keto- $\alpha$-ionone, 2-bydroxy-5-keto- $\alpha$-ionone, 3, 4-dihydroy-aionone 


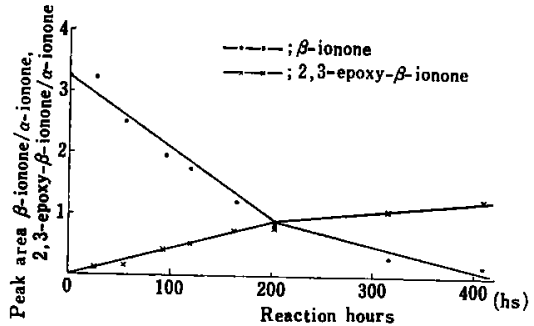

Fig. 3. Area relations of $\beta$-ionone and 2 , 3-epoxy- $\beta$-ionone by GLC

Table 3. Oxydation Value* of organic compouns on the oxidation of $\beta$-Ionone

\begin{tabular}{|c|c|c|c|}
\hline \multicolumn{2}{|l|}{ Proteins } & \multicolumn{2}{|l|}{ Carbohydrates } \\
\hline Gelatine & 6.50 & Corn starch & 2.40 \\
\hline Soybean protein & 1.35 & Glucose & 1.46 \\
\hline Casein & 1.16 & Fructose & 0.45 \\
\hline Albumin & 0.96 & Vitamins & \\
\hline Zein & 0.26 & Vitamin $K_{s}$ & 2.13 \\
\hline Gluten & 0.21 & Vitamin Ba & 0.92 \\
\hline Amimo acids & & Organic acids & \\
\hline L-Phenyl alanine & 0.96 & Citric acid & 1.76 \\
\hline L-Leucine & 0.92 & Folic acid & 1.16 \\
\hline L-Glutamic acid & 0.78 & Oxalic acid & 0.92 \\
\hline L-Tryptophan & 0.54 & L-Ascorbic acid & 0.63 \\
\hline L-Histidine & 0.37 & Plant oils & \\
\hline L-Methionine & 0.19 & Soybean oil & 1.39 \\
\hline \multicolumn{2}{|c|}{ Fatty acids and Alchols } & Camellia oil & 0.89 \\
\hline Palmitic acid & 0.18 & Flavons & \\
\hline Myristic acid & 0.18 & Quercetin & 0 \\
\hline Myristyl alcohol & 0.19 & Rutin & 0 \\
\hline \multirow[t]{3}{*}{ Stearyl alcohol } & 0.10 & Others & \\
\hline & & Lecithin & 1.83 \\
\hline & & $\mathrm{NaCl}$ & 1.53 \\
\hline
\end{tabular}

* When $\beta$-ionone was converted to 2,3-epoxy- $\beta$-ionone after $200 \mathrm{hrs}$. irradiation, oxydation value is one. In this table the value larger than one suggests the promotion of oxidation and that smaller than one suggests the protection.

前記のような知見から $\beta$-ヨノンの溶液に 各種添加物 を加えたのち，200 時間反応を行ない， $\beta$-ヨノンの酸化 の程度を検討した。実駼は蛋白質， フミノ酸，高級脂肪 酸, 高級アルコール，炭水化物，ビタミン，有機酸，植 物油,フラボンに分けて行なった。その結果は Table 3 に示すようである。表中の数值は対照として $\beta$-ヨノン のみを反応させたとき，ピーク面積比が 200 時間後で， 1.00 であることから，1.00 より数値の大きいもの酸 化を促進し，逆に小さいものは酸化を抑制する勃果があ
ると判断した。

この Table からわかることは蛋白質, 炭水化物, ビ タミン，有機酸，植物油類ではその種類によって差があ り，一定の傾向は見られなかった。フミノ酸では一般偟 対照上り低い值を得たが，とくに硫黄8》含むむの，ま た窒素を環内に 持つむのは酸化を抑制する傾向があっ た。フラボン類は一般に抗酸化性を有するといわれる が9，この実験においても顕著な傾向を示した。最後に 興味あることは高級脂肪酸またはアルコール類であり， これらは全般に高い抑制值を示した。

従来から抗酸化性物質はそのもの自体の酸化により他 を保葌するような機檴のものが多かった。この点高級脂 肪酸またはフルコール類ではその保護作用が異なるるの と考えられる。現在その機構は明確ではないが，おそら く溶液中におけるこれらの物質の物理的な作用により保 護されているように思える。

終りに実験を進めるに当り貫重な御助言を晹わった本 学教授中林敏郎博士に深謝する。

要 約

(1) 香りの熟成の 1 つの要因と考元られる自動酸化の 機構を知るため，三重項酸䋕酸化反応が応用できること を知った。

(2) ヨノンの酸化におよぼす添加物の影響を知るため GLC による，生成エポキショノンの量と残存ヨノンの 量を知ることで調べることができた。

(3) ヨノンの酸化に対しては高級脂肪酸または高級了 ルコールが強い保護作用を有していた。

\section{文献}

1）伊奈和夫：食品工誌，20，43（1973）

2) 伊奈和夫・平野貫治: 食品工誌, 投稿中.

3) Ina, K. and Етон, H.: Agr. Biol. Chem., 36, 1091 (1272).

4) Viani, R., Bricout, J., Müggler-Chavan, F., Reymond, D. and Egli, R.H.: Helv. Chim. Acta, 52, 887 (1969).

5) Ina, K. and Eтон, H.: Agr. Biol. Chem., 35, 962 (1971).

6) Sakan, T., Isoe, S. and Hyron, S. B., Tetrahedron Letters, 1623 (1967).

Ina, K., Sakato, Y. and Fukami, H.: Tetrahedron Letters, 2777 (1968).

Bricout, J., Viani, R., Müggler-Chavan, F., Marison, J.P., RaYMond, D. and Egli. R.: Helv. Chim. Acta, 50, 1517 (1967).

7) Pousset, J. L. and Poisson, L.: Tetrahedron Letters, 1173 (1969).

8）名武昌人：栄養と食糃，24，63 (1971).

9）山口一孝: 植物成分分析法, 上巻, 南江堂, p. 207 (1958).

（昭和 47 年 7 月 3 日受理） 